\title{
Kepemilikan Saham oleh Buruh sebagai Upaya Penegakan Sistem Ekonomi Pancasila
}

\author{
Epri Wahyudi \\ YLBHI-Lembaga Bantuan Hukum (LBH) Yogyakarta, Indonesia \\ epriwahyudi@yahoo.com
}

\begin{abstract}
This article discusses the conceptual idea in addressing the situation of workers in Indonesia who are perceived not to have the right to prosper in the work already owned. In economics, labours play an important role because they are the wheels in driving the production of goods and services. The unfilled labour rights to live prosperous is caused by the absence of their authority to contribute in determining a policy within a company. To overcome the imbalance of bargaining position between workers and employers, a regulation or policy is required to materialise access to share ownership within the company. By owning shares, workers have the right to convey ideas in determining company policy. In addition, labours will also easily access all company information including company report approval. It concludes that the ownership of shares by labours in the company is a necessity and an effort to realise Pancasila Economic System in order to fulfill the more substantive labour rights.
\end{abstract}

KEYWORDS: Share Ownership, Labours, Pancasila Economic System.

Copyright $\odot 2017$ by Author(s)

This work is licensed under a Creative Commons Attribution-ShareAlike 4.0 International License. All writings published in this journal are personal views of the authors and do not represent the views of this journal and the author's affiliated institutions.

\section{HOW TO CITE:}

Wahyudi, Epri. "Kepemilikan Saham oleh Buruh sebagai Upaya Penegakkan Sistem Ekonomi Pancasila" (2017) 4:2 Lentera Hukum 11l-124.

Submitted: August 24, 2017 Revised: August 28, 2017 Accepted: August 28, 2017 


\section{RELASI PERKAWINAN DAN PERCERAIAN}

Keberadaan Buruh disuatu negara merupakan salah satu unsur penting dalam pergerakan ekonomi nasional. Disadari atau tidak, bahwa tanpa buruh negara tidak akan pernah mampu untuk menghasilkan apa-apa, karena pasti tidak pernah akan adanya investasi yang masuk di negara tersebut guna melakukan aktifitas produksi baik barang maupun jasa. Indonesia merupakan negara yang jumlah buruhnya termasuk tinggi, ${ }^{1}$ namun keadaan ketenagakerjaan di Indonesia belumlah seperti apa yang diharapkan para buruh, yakni memberikan sumbangsih untuk mewujudkan kesejahteraan para buruh. Hal tersebut terlihat dari cara buruh merayakan hari buruh (mayday) yang jatuh pada 1 mei setiap tahunnya, dimana dalam setiap peringatan tersebut para buruh yang tergabung dalam serikat buruh selalu menuntut kepada pemerintah dan pengusaha untuk dapat mensejahterakan dirinya melalui kebijakankebijakan yang mampu mengakomodir hak-hak buruh seperti upah yang layak, hubungan kerja yang baik, cuti kerja, dan lain sebagainya.

Hal tersebut merupakan suatu pembuktian bahwa keadaan buruh di Indonesia masih jauh dari apa yang di impikan dan dicita-citakan oleh buruh. Padahal jika merujuk pada Pancasila sebagai pandangan hidup negara Indonesia, khususnya pada sila kelima yang menyatakan bahwa "keadilan bagi seluruh rakyat Indonesia" dan kemudian juga UUD 1945 sebagai landasan dasar pengaturan dalam hidup berbangsa dan bernegara setelah Pancasila, yang dinyatakan dalam pasal 27 ayat (2) UUD 1945 bahwa "Tiap-tiap warga negara berhak atas pekerjaan dan penghidupan yang layak bagi kemanusiaan" yang kemudian juga ditegaskan dalam pasal 28D ayat (2) UUD 1945 yang menyatakan bahwa "setiap orang berhak untuk bekerja serta mendapat imbalan dan perlakuan yang adil dan layak dalam hubungan kerja", oleh karena itu jelas menunjukkan bahwa peran negara tidak hanya menjamin seseorang agar mampu mendapatkan suatu pekerjaan saja, melainkan lebih dari itu. Bahwa negara harus mampu mewujudkan kesejahteraan kepada buruh melalui pekerjaan yang ia miliki.

Karena pada dasarnya, terjaminnya hak atas pekerjaan belum tentu dengan sendirinya menjamin kesejahteraan bagi setiap warga negara, hal ini karena bisa saja seseorang dipekerjakan dengan tata cara yang tidak sesuai dengan cara-cara yang baik, seperti tingkat upah yang minim, kebijakan yang menyengsarakan, dan hal-hal lain yang hanya akan menyebabkan kehidupan buruh tidak dapat berkembang dengan baik. Kondisi yang demikian itu pada dasarnya diakibatkan karena posisi tawar buruh masih dianggap lemah ketika dihadapkan dengan pengusaha. Dalam banyak kebijakan tak jarang suara buruh tidak diikut sertakan dalam pengambilan keputusan, kebijakan hanya diambil secara sepihak oleh pengusaha, sekalipun diikutsertakan dalam menentukan kebijakan posisi tawar buruh selalu dibawah pengusaha.

1 Menurut data dari Badan Pusat Statistik bahwa sampai bulan Agustus 2016 total tenaga kerja di Indonesia adalah sebanyak 114.819 .199 orang dan secara spesifik tercatat sebagai pekerja/ buruh adalah sebanyak 44.434.390 orang, dalam https://www.bps.go.id/linkTabelStatis/ view/id/971 diakses pada tanggal 25 Januari 2017. 
Oleh karena itu untuk dapat meningkatkan posisi tawar kepada buruh, maka buruh juga harus mampu menyampaikan pendapat dan gagasannya dalam setiap forum pengambilan kebijakan dalam suatu perusahaan. Namun sebagaimana yang telah diketahui bersama bahwa mayoritas keberadaan perusahaan di Indonesia yang mengakomodir para pekerja/buruh dalam skala besar adalah jenis perusahaan yang berbadan hukum Perseroan Terbatas (PT). Oleh sebab itu yang perlu diperhatikan bersama adalah bahwa forum pengambilan kebijakan suatu perusahaan yang tertinggi tersebut adalah berada pada forum Rapat Umum Pemegang Saham (RUPS). Dengan mengikuti ketentuan tersebut maka mau tidak mau buruh harus ikut andil dalam kepemilikan saham yang memiliki hak suara dalam suatu perusahaan. ${ }^{2}$ Hal ini supaya buruh dapat memiliki suara dalam menentukan arah kebijakan perusahaan yang dapat mengakomodir kebutuhan semua pihak terutama dalam upaya mensejahterakan kehidupan buruh, oleh karena itu maka yang harus menjadi pemikiran dan perhatian bersama adalah bagaimana buruh dapat mengakses kepemilikan saham dalam suatu perusahaan.

\section{KEPEMILIKAN SAHAM BERSAMA SEBAGAI GAMBARAN SISTEM EKONOMI PANCASILA}

Pancasila adalah sebuah pedoman hidup (way of life) bangsa yang digunakan sebagai petunjuk dalam menjalankan kehidupan sehari-hari masyarakat Indonesia baik dari segi sikap maupun perilaku. Karena di dalam Pancasila mengandung nilai-nilai keagamaan, kemanusiaan, politik, sosial, budaya, dan ekonomi. Dalam hal nilai-nilai Pancasila terkait dengan ekonomi menekankan terhadap adanya keadilan sosial bagi seluruh rakyat Indonesia, dalam arti bahwa kebijakan-kebijakan ekonomi yang disusun oleh negara harus mampu mewujudkan kesejahteraan yang adil terhadap semua bangsa Indonesia. Kemudian untuk dapat mengatur kehidupan dan perkembangan Bangsa Indonesia, maka diperlukan kendali yaitu hukum yang berlandaskan pada nilai-nilai yang terdapat dalam Pancasila dan juga menjadi pijakan dalam melakukan penyusunan peraturan perundang-undangan, yang kemudian biasa disebut dengan konstitusi (UUD 1945). Sehingga kemudian segala ketentuan peraturan perundang-undangan baik dalam tingkat undang-undang sampai pada tingkat peraturan yang paling bawah yang mengatur kehidupan berbangsa dan bernegara haruslah berpedoman pada hukum dasar tersebut yaitu UUD 1945.

2 Klasifikasi saham sebagaimana dimaksud pada Pasal 53 Ayat (3) dan (4) UU PT adalah sebagai berikut: a. Saham dengan hak suara atau tanpa hak suara; b. Saham dengan hak khusus untuk mencalonkan anggota Direksi dan/atau angora Dewan Komisaris; c. Saham yang setelah jangka waktu tertentu ditarik kembali atau ditukar dengan klasifikasi saham lain; d. Saham yang memberikan hak kepada pemengangnya untuk menerima dividen lebih dahulu dari pemegang saham klasifikasi lain atas pembagian dividen secara kumulatif atau nonkumulatif; e. Saham yang memberikan hak kepada pemegangnya untuk menerima lebih dahulu dari pemegang saham klasifikasi lain atas pembagian sisa kekayaan perseroan dalam likuidasi. 
Artinya jelas bahwa segala sesuatu yang berkaitan dengan kehidupan berbangsa dan bernegara tak terkecuali dalam pengaturan masalah ekonomi khususnya dalam bidang perburuhan atau ketenagakerjaan, harus berpegang teguh terhadap nilai-nilai yang merupakan manifestasi dari sila-sila yang terkandung dalam Pancasila dan Undang-Undang Dasar 1945 yang merupakan dasar hukum bagi keberlangsungan dan perkembangan dalam hidup berbangsa dan bernegara. Karena dalam hal ini dengan merujuk sila kelima Pancasila yang menyatakan "keadilan sosial bagi seluruh rakyat Indonesia", kemudian UUD 1945 khususnya pada pasal 33 ayat (1) yang menyatakan bahwa "perekonomian disusun sebagai usaha bersama berdasarkan atas asas kekeluargaan" dan pasal 33 ayat (4) yang menyatakan bahwa "perekonomian nasional diselenggarakan berdasar atas demokrasi ekonomi dengan prinsip kebersamaan, efisiensi, berkeadilan, berkelanjutan, berwawasan lingkungan, kemandirian, serta dengan menjaga keseimbangan kemajuan dan kesatuan ekonomi nasional" adalah merupakan bentuk sebuah sistem perekonomian berdasarkan nilai-nilai yang terkandung dalam Pancasila.

Menurut Prof. Mubyarto, bahwa sistem ekonomi Pancasila adalah sistem ekonomi yang digali dan dibangun melalui nilai-nilai yang dianut dalam kehidupan masyarakat secara langsung yang berasal dari nilai-nilai agama, kebudayaan, adatistiadat, atau norma-norma lain yang membentuk perilaku ekonomi masyarakat Indonesia. ${ }^{3}$ Oleh karena itu dengan berpedoman pada sistem ekonomi Pancasila tersebut maka mau tidak mau dalam konteks pengaturan perburuhan atau ketenagakerjaan juga harus berpegang teguh pada nilai-nilai yang terkandung dalam Pancasila. Sehingga kemudian konsep pengaturan perburuhan atau ketenagakerjaan di Indonesia dengan Pancasila adalah hubungan perburuhan yang berlandaskan Pancasila.

Kemudian menurut apa yang disamapaikan oleh G. Kartasapoetra, bahwa hubungan perburuhan dengan Pancasila merupakan hubungan antara pelaku dalam proses produksi barang dan jasa atau jelasnya hubungan antara buruh, pengusaha, dan pemerintah yang didasarkan atas nilai yang merupakan manifestasi dari keseluruhan sila-sila Pancasila dan Undang-Udang Dasar 1945 yang tumbuh dan berkembang dalam kepribadian bangsa dan kebudayaan nasional. ${ }^{4}$

Sehingga jika merujuk pada konsepsi sistem ekonomi dan perburuhan yang dilandaskan pada nilai-nilai Pancasila yang kemudian diatur melalui ketentuan dalam UUD 1945, maka dapat ditafsirkan bahwa tujuan dari sistem ekonomi yang berlandaskan pada pancasila tersebut adalah untuk mewujudkan keadilan sosial bagi seluruh rakyat Indonesia sebagaimana dimaksud dalam sila ke lima Pancasila melalui cara-cara nasionalistik dan kerakyatan (demokrasi) serta gotong royong (kekeluargaan), sehingga kemudian akan mewujudkan prinsip pembagian keuntungan dan kerugian bersama (profit and lose sharing) dan partisipasi para pekerja (employee participation) sehingga lebih menjamin ketentraman, ketenangan, dan keberlanjutan

\footnotetext{
Mubyarto, Ekonomi Pancasila (Yogyakarta: BPFE-UGM, 2002), hlm. 68.

4 G. Kartasapoetra. Dkk, Hukum Perburuhan di Indonesia Berlandaskan Pancasila (Jakarta: Sinar Grafika, 1986), hlm. 21-22.
} 
usaha, serta kesejahteraan semua pihak. ${ }^{5}$ Oleh karena itu setidaknya harus ada beberapa asas yang mampu memaknai konsep sistem ekonomi dan perburuhan Pancasila tersebut. Adapun asas asas tersebut diantaranya adalah sebagai berikut:

\section{A. Asas Kekeluargaan/Usaha Bersama}

Pada prinsipnya perusahaan adalah milik bersama antara pengusaha dengan buruh, oleh karena itu maka konsep berfikir yang seharusnya adalah bagaimana kepemilikan terhadap aset perusahaan (modal) dapat diusung, dimiliki, dan ditanggung secara bersama antara pendiri perusahaan dengan buruh yang akan menjalankan perusahaan. sehingga kemudian akan membentuk tanggungjawab bersama agar dapat bekerja sama dalam memajukan perusahaan tersebut.

Dengan adanya pola berfikir tersebut dilain akan mendatangkan keuntungan bersama dalam perusahaan, pastinya juga akan mampu mendorong pertumbuhan ekonomi nasional kearah yang jauh lebih baik. Hal tersebut sebagaimana dinyatakan dalam pasal 33 ayat (1) UUD 1945 yang menyatakan bahwa "Perekonomian disusun sebagai usaha bersama berdasar asa kekeluargaan". Menurut G. Kartasapoetra dkk, bahwa perusahaan yang seharusnya tumbuh di Indonesia adalah perusahaan yang dalam kegiatan hendaknya memenuhi beberapa hal, yakni: ${ }^{6}$

a. Menganggap bahwa para tenaga kerja sebagai partner yang akan menyukseskan tujuan dari usaha

b. Memberikan keseimbangan yang layak atas jasa-jasa para tenaga kerja yang dikerahkan sebagai seorang partner supaya lebih produktif

c. Menjalin hubungan baik dengan para tenaga kerja, sehingga dalam melaksanakan kegiatan produksi dan distribusi para tenaga kerja turut serta memiliki perusahaan dan kemudian akan mampu menumbuhkan rasa tanggungjawab bersama.

Selain itu menurut Michael Poole, Lansbury, dan Wailes tindakan agar asas kekeluargaan dapat terwujud dalam lingkungan perseroan adalah dengan melakukan beberapa tindakan. Tindakan-tindakan tersebut yaitu: ${ }^{7}$

a. Pekerja memiliki inisiatif untuk meningkatkan partisipasi pekerja/ buruh dalam mengambil keputusan

b. Serikat pekerja memiliki inisiatif untuk melakukan penyusunan kesepakatan kerja bersama (KKB) yang demokratis

c. Ada inisiatif dalam proses manajerial dengan melaksanakan program kepemilikan saham oleh pekerja, dan

d. Adanya kebijakan negara melalui produk peraturan perundang-undangan yang mendukung.

5 Mubyarto, Demokrasi Ekonomi dan Demokrasi Industrial, dalam http://jer.mubyarto.org/ edisi_17/artikel_3.htm diakses pada 25 Januari 2017

6 G. Kartasapoetra. Dkk, supra note 4, hlm. 7.

7 Dalam Revrisond Baswir, Asas Kekeluargaan, dalam http://mubyarto.org/opinilpost.php?id=5 diakses pada 25 Januari 2017 


\section{B. Asas Demokrasi Ekonomi}

Bahwa sistem ekonomi Indonesia bukanlah sistem ekonomi yang menganut sistem ekonomi liberal, melainkan sistem ekonomi yang berlandaskan pada demokrasi ekonomi. Pancasila, terutama sila kelima yang mengamanatkan negara harus mampu mewujudkan keadilan sosial bagi masyarakatnya, dan kemudian dalam pasal 33 ayat (4) UUD 1945 yang menyatakan bahwa "Perekonomian nasional diselenggarakan berdasar atas demokrasi ekonomi dengan prinsip kebersamaan, efisiensi berkeadilan, berkelanjutan, berwawasan ligkungan, kemandirian, serta dengan menjaga keseimbangan kemajuan dan kesatuan ekonomi nasional". Jelas menunjukkan bahwa sistem ekonomi yang ada dianut oleh Indonesia haruslah diusung dengan cara-cara demokratis, dimana konsentrasinya adalah terakomodirnya kepentingan ekonomi ${ }^{8}$ semua masyarakat Indonesia.

Dalam hal ini, asas demokrasi ekonomi dalam perusahaan dapat diwujudkan dengan tindakan-tindakan yang nyata, yaitu dengan melakukan employee participation, profit sharing, dan share ownership. Dengan mengaplikasikan hal-hal tersebut dalam perusahaan akan menguntungkan perusahaan itu sendiri. Menurut Michael Poole salah seorang pakar ekonomi, berdasarkan penelitiannya terhadap 303 perusahaan di Inggris, ada 5 (lima) keuntungan jika perusahaan dapat menerapkan aturan pembagian laba dan pemilikan saham oleh buruh atau karyawan, yaitu: ${ }^{9}$

a. Adanya komitmen moral yang tumbuh dari para pekerja/buruh (moral commitment);

b. Keterikatan pekerja/buruh (staff retention) karena merasa turut serta dalam kepemilikan perusahaan;

c. Keterlibatan pekerja/ buruh (employee involvement);

d. Perbaikan kinerja hubungan industrial (improved industrial relations performance); dan

e. Perlindungan dari pengambilalihan dari perusahaan lain (protection against takeover).

\section{KEPEMILIKAN SAHAM OLEH BURUH DAN PERAN NEGARA}

Bahwa pada prinsipnya negara Indonesia harus selalu berpegang teguh terhadap kesejahteraan masyarakatnya, negara harus berperan aktif dan tidak boleh membiarkan begitu saja penyelenggaraan persaingan ekonomi dilakukan secara bebas (Laissez Faire), karena kemudian peran negara sangat dibatasi (minimal government intervene). ${ }^{10}$ Oleh karena itu dalam hal ini negara harus bersifat aktif guna mencapai negara kesejahteraan

8 Kepentingan ekonomi masyarakat yang dimaksud dalam hal ini adalah kepentingan untuk menuju hidup yang sejahtera, terpenuhinya kebutuhan pokok, mampu untuk survive dan berkembang dalam kehidupan sehari-hari.

9 Mubyarto, Demokrasi Ekonomi dan Demokrasi Industrial, dalam http://jer.mubyarto.org/edisi_17/artikel_3.htm diakses pada 25 Januari 2017

10 Lalu Husni, Pengantar Hukum Ketenagakerjaan Indonesia, Edisi Revisi Cet. Ke-10 (Jakarta: Raja Grafindo, 2010), hlm. 14. 
(walfare state) sebagaimana yang di agung-agungkan dalam konsep negara modern, namun bukan negara kesejahteraan yang rakyatnya pasif dan pemerintahnya sibuk mempersiapkan segala macam pelayanan kesejahteraan sosial, melainkah saling terintegrasi antara keaktifan negara melalui organ pemerintahan dan rakyatnya dalam kehidupan sehari-hari.

Jika merujuk pada Pancasila khususnya sila kelima yang menyatakan bahwa "Keadilan sosial bagi seluruh rakyat Indonesia", pembukaan UUD 1945 alinea ke empat yang menyatakan bahwa salah satu tujuan dari Negara Indonesia yaitu "memajukan kesejahteraan umum", dan dalam ketentuan pasal 1 ayat (3) UUD 1945 yang menyatakan bahwa "negara Indonesia adalah negara hukum" maka jelas bahwa konsep negara yang diusung oleh negara Indonesia adalah negara hukum kesejahteraan (rechtstaat walfare). Oleh karena itu segala macam bentuk peraturan yang ada di Indonesia selain bertujuan untuk menata kehidupan berbangsa dan bernegara, juga harus mampu mewujudkan kesejahteraan dalam kehidupan berbangsa dan bernegara.

Selain itu bahwa, secara normatif UUD 1945 menjamin hak asasi setiap manusia. Oleh sebab itu, dalam konteks hak asasi manusia maka negara khususnya pemerintah memiliki kewajiban untuk melakukan penghormatan (respect), perlindungan (protect), pemajuan (fartherance), penegakan (enforcement), dan pemenuhan (fulfilment). Hal tersebut sebagaimana dinyatakan dalam pasal 28I ayat (4) UUD 1945 yang menyatakan bahwa "perlindungan, pemajuan, penegakan, dan pemenuhan hak asasi manusia adalah tanggung jawab negara, terutama pemerintah".

Oleh karena itu berkaitan dengan kepemilikan saham oleh buruh, maka negara memiliki kewenangan aktif untuk mengintervensi keadaan dimana pemerintah membuat suatu peraturan atau kebijakan yang secara tegas menjamin akses buruh terhadap kepemilikan saham dalam suatu perusahaan.

Bahwa sampai saat ini masalah hak pekerja/ buruh terhadap kepemilikan saham dalam suatu perusahaa belumlah diatur di dalam sebuah peraturan perundangundangan secara terperinci. Bahwa ketentuan peraturan yang ada saat ini belumlah cukup mampu untuk mengakomodir hak buruh yang mampu membawa buruh dalam taraf hidup yang lebih baik. Peraturan yang ada saat ini hanya membuat keadaan buruh kepada status quo dalam menuju kesejahteraan. Bahwa tidak adanya peraturan yang mampu mengakomodir hak buruh terhadap kepemilikan saham dalam sebuah perusahaan membuat posisi tawar akan hak dan kewajiban antara buruh dengan pengusaha yang tidak seimbang, dimana buruh selalu ditempatkan dalam posisi yang ada di bawah.

Oleh karena itu maka negara harus membuat aturan tersendiri yang mengatur tata cara bagaimana buruh mampu mengakses kepemilikan saham di suatu perusahaan tempat ia bekerja. Hal tersebut sebagaimana pendapat yang disamapaikan oleh Philip Nonet dan Selznick, yang menyatakan bahwa untuk menjadi responsif, maka hukum perlu terbuka dalam banyak hal, partisipatif, dan mampu untuk mengantisipasi hal-hal 
dalam situasi sulit. Sehingga hukum yang responsif mampu mendorong suatu pendekatan yang berpusat pada suatu masalah. ${ }^{\text {ll }}$

Sebagai contoh, masalah yang selalu menjadi perhatian oleh para buruh adalah masalah kesejahteraan yang di dalamnya termasuk masalah upah, jam kerja, dan lain sebagainya yang selalu menjadi tuntutan para buruh pada saat perayaan hari buruh (mayday) yang tidak kunjung untuk dipenuhi. Hal tersebut adalah karena posisi tawar buruh sangatlah rendah dihadapan pengusaha. Perlu adanya suatu peraturan dimana buruh dapat memiliki saham dalam suatu perusahaan.

Hal ini supaya validitas hukum terkait perburuhan yang tidak berkembang dan pelaksanaannya dalam kehidupan sehari-hari yang semakin dipertanyakan. Sebagaimana kritik terhadap hukum yang disampaikan oleh Philippe Nonet dan Selznick bahwa hukum selalu ditujukan kepada tidak memadainya hukum sebagai alat perubahan dan sebagai alat untuk mencapai keadilan substantif karena telah bekerja sebagai alat kekuasaan. Dimana kebijakan hukum sangatlah jelas yaitu berpihak dan menguntungkan atau memberikan keistimewaan kepada kelompok atau golongan tertentu. $^{12}$

\section{URGENSI KEPEMILIKAN SAHAM OLEH BURUH DALAM PERUSAHAAN}

Bagian ini akan menguraikan urgensi kepemilikan salam oleh buruh dalam perusahaan. Pembahasan mencakup akses hak suara dalam RUPS, akses hak atas informasi dan hak kesetaraan buruh dalam perusahaan.

\section{A. Akses Terhadap Hak Bersuara dalam RUPS}

Sebagaimana diketahui bersama bahwa setiap orang yang memiliki saham dalam suatu perusahaan dapat menghadiri Rapat Umum Pemegang Saham (RUPS) dan menggunakan hak suaranya sesuai dengan jumlah saham yang dimilikinya. ${ }^{13}$ Oleh karena itu setiap orang yang tidak memiliki saham dalam perusahaan maka ia sama sekali tidak memiliki hak untuk dapat bersuara dalam perusahaan tersebut, sekalipun orang tersebut memiliki jabatan direktur utama. Lain halnya dengan seseorang yang turut serta dalam kepemilikan saham dalam suatu perusahaan, ia berhak mendapatkan hak untuk bersuara dalam forum RUPS dalam suatu perusahaan walaupun ia hanya seorang buruh tingkat bawah sekalipun.

Hal tersebut tentu sejalan dengan pemikiran bahwa buruh harus turut andil dalam kepemilikan saham dalam suatu perusahaan, sehingga kemudian buruh mampu untuk menyampaikan apa yang menjadi ide dan gagasannya dalam menjalankan roda perusahaan, sehingga kemudian buruh dapat merasakan kesejahteraan, dan tentu saja

11 Philippe Nonet dan Selznich, Hukum Responsif, Pilihan di Masa Transisi, diterjemahkan oleh Perkumpulan untuk Pembaharuan Hukum Berbasis Masyarakat dan Ekologis (HuMa) (Jakarta: HuMa, 2003), hlm. 35-37.

12 Ibid, hlm. 35-37.

13 Lihat pasal 85 ayat (1) Undang-Undang Nomor 40 Tahun 2007 tentang Perseroan Terbatas. 
kemudian tidak ada lagi yang disebut dengan ketimpangan sosial dalam kehidupan bermasyarakat.

Hal ini sebagaimana pendapat yang disampaikan oleh Satjipto Rahardjo, bahwa dengan kepemilikan seseorang akan dapat dengan mudah menyampaikan ide dan gagasan, dan kemudian dapat menjadi lambang kemenangan dominasi suatu pemikiran. Sehingga kemudian mampu untuk memenuhi hak-hak kesejahteraannya. ${ }^{14}$ Bahkan lebih dari itu, menurut Dias R.W.M dalam bukunya Jurisprudence menyatakan bahwa dengan kepemilikan, seseorang tidak hanya akan mendapatkan sebuah kesejahteraan dari apa yang ia miliki, lebih dari itu bahwa dengan kepemilikan juga akan dapat meningkatkan kedudukan sosial dari setiap orang dalam tatanan kehidupan masyarakat. $^{15}$

\section{B. Akses Terhadap Hak Atas Informasi}

Informasi adalah sesuatu hal yang sangat penting dalam kehidupan sehari-hari dan merupakan kebutuhan pokok setiap orang bagi pembangunan pribadi, lingkungan sosial, dan pengembangan dalam kehidupan bermasyarakat. Dengan adanya informasi maka seseorang akan dapat berperan aktif di dalam proses pengambilan kebijakan serta menciptakan keadaan menjadi lebih transparan dan akuntabel dalam segala hal. Bahwa selama ini buruh belum bisa mengakses semua informasi tentang perusahaan dengan sepenuhnya. Oleh karena itu dengan menjadi bagian dari kepemilikan saham dalam perusahaan, tentu saja buruh akan dengan mudah mengakses segala macam bentuk informasi dari perusahaan. Karena pada prinsipnya bahwa pemegang saham memiliki hak untuk dapat mengakses segala macam bentuk informasi yang ada dalam perusahaan.

Dengan adanya informasi yang didapatkan oleh buruh secara penuh dan rigid, tentu saja buruh bisa dengan langsung mendorong dan mengawasi segala macam kebijakan yang akan keluarkan oleh perusahaan. Selain itu bahwa dengan adanya informasi yang mampu diakses oleh semua pihak maka hal tersebut akan menciptakan demokrasi yang substansi dalam suatu perusahaan. Menurut Kurniawan bahwa keterbukaan informasi kepada semua pihak atas perusahaan akan mewujudkan perusahaan dalam pencapaian dan pelaksanaan Good Coorporate Governance (GCG). Hal tersebut karena prinsip-prinsip mendasar yang harus ada dalam konsep Good Coorporate Governance tersebut diantaranya adalah dengan adanya prinsip transparansi, akuntabilitas, keadilan, dan pertanggungjawaban atas segala sesuatu yang ada dalam perusahaan. $^{16}$

14 Satjipto Rahardjo, Ilmu Hukum, Cet. ke-8 (Bandung: PT. Citra Aditya Bakti, 2014), hlm. 66.

15 Ibid, hlm. 66.

16 Kurniawan, Hukum Perusahaan Karakteristik Badan Usaha Berbadan Hukum dan Tidak Berbadan Hukum di Indonesia (Yogyakarta: Genta Publishing, 2014), hlm. 75. 


\section{Hak untuk Kesetaraan}

Bahwa pada prinsipnya saham adalah merupakan sumber daya ekonomi dalam setiap perusahaan yang berbadan hukum perseroan terbatas. Sehingga jika dilogikakan dalam banyak hal, khususnya dalam interaksi antara warga negara yang memiliki dan menguasai sumber daya alam ekonomi (kaum kapital) dengan warga negara yang tidak memiliki dan menguasai sumber daya alam ekonomi seperti masyarakat kebanyakan (buruh) akan mengakibatkan sebuah ketimpangan dalam posisi tawar (bergaining position) ketika dihadap dalam persoalan yang sama dalam menentukan sebuah kebijakan. Terlebih apabila kondisi yang demikian itu didukung oleh corak hukum yang mencerminkan aturan-aturan yang hanya menjamin dan memperkuat posisi kegiatan ekonomi kapitalis. Sehingga kemudian membuat masyarakat kapitalis semakin hari semakin kuat dan sebaliknya masyarakat buruh yang semakin hari semakin tidak berdaya. ${ }^{17}$ Oleh sebab itu untuk dapat menyeimbangkan posisi tawar (bergaining position) antara masyarakat kebanyakan (buruh) dengan masyarakat kapital (pengusaha) maka sudah seharusnya harus saling berbagi sumber daya ekonomi tersebut yaitu kepemilikan saham untuk semua pihak, tak terkecuali oleh para buruh ditingkat yang paling bawah. Sehingga kemudian semua pihak menjadi bagian dari pemilik perusahaan dan kemudian mau tidak mau harus setara kedudukannya di hadapan anggaran dasar perusahaan.

\section{TATA CARA PEMBERIAN SAHAM KEPADA BURUH}

Bagian ini akan menguraikan megenai tata cara pemberian saham kepada buruh. Tata cara tersebut di antaranya melalu pelepasan atau penjualan saham yang telah ada, serta membuat saham baru.

\section{A. Melalui Pelepasan/ Penjualan Saham yang Telah Ada (Divestasi/Divesment)}

Istilah divestasi berasal dari terjemahan bahasa inggris, yaitu divestment, yang pengertiannya tidak saja hanya berarti pengalihan keuntungan, tetapi lebih penting lagi adalah pengalihan kontrol terhadap jalannya perusahaan. ${ }^{18}$ Kemudian Sally Wehmeier juga mengemukakan bahwa divestasi adalah sebuah ketentuan yang mengatur tentang penjualan saham yang dimiliki oleh perusahaan atau cara mendapatkan uang dari investasi yang dimiliki oleh seseorang (divesment the act selling the shares you have bought in company or taking money away from where you invested). ${ }^{19}$

Kemudian Menurut Abdul Moin bahwa upaya divestasi dilakukan karena dua alasan, yaitu divestasi secara sukarela. ${ }^{20}$ Divestasi ini merupakan pengalihan saham

17 Lalu Husni, supra note 10, hlm. 15.

18 Salim HS, Hukum divestasi di Indonesia (Jakarta: Penerbit Erlangga, 2010), hlm. 31.

19 Salim HS dan Erlies Septiana Nurbani, Hukum Divestasi Di Indonesia (Pasca Putusan Mahkamah Konstitusi RI Nomor 2/SKLN-X/2012), Edisi Revisi (Jakarta: Rajawali Pers, 2013), hlm. 3.

20 Abdul Moin, Merger, Akuisisi, \& Divestasi, Edisi Ke-2 (Yogyakarta: Ekonisa Kampus Fakultas Ekonomi UII, 2007), 334-336. 
atau aset yang dilakukan atas sebuah kehendak atau kemauan sendiri dari perusahaan yang bersangkutan, yang meliputi: mengembalikan perusahaan kepada kompetensi inti (core competence), menghindari sinergi yang negatif, tidak menguntungkan secara ekonomis, permasalahan keuangan perusahaan, terdapat perubahan strategi perusahaan, hendak mendapatkan uang kas dengan segera, dan alasan individu pemegang saham. Hal-hal tersebutlah yang biasanya mejadi faktor divestasi secara sukarela.

Selain itu dikenal juga dengan divestasi karena terpaksa. ${ }^{21}$ Cara ini merupakan pengalihan saham atau aset yang dilakukan oleh perusahaan karena adanya tekanantekanan dari pihak lainnya seperti pemerintah, atau permintaan kreditur. Dalam hal tekanan dari pemerintah adalah karena biasanya perusahaan tersebut telah sampai pada praktik monopoli yang menyebabkan perusahaan lain tidak bisa bersaing dipasar produk yang sama dan melanggar undang-undang anti monopoli. Dalam konteks buruh, tentu saja divestasi saham atau aset yang dilakukan dengan cara ini bertitik pada rasionalisasi bahwa buruh adalah subjek yang turut berhak dalam pengendalian sebuah perusahaan untuk menentukan kebijakan-kebijakan perusahaan yang dapat menjadikan semua pihak sejahtera atas pekerjaan yang dimiliki dalam perusahaan tersebut. Oleh karena itu mau tidak mau tentu saja pemerintah harus mampu mengakomodir hal tesebut sebagai upaya paksa terhadap perusahaan untuk melakukan divestasi sebagian saham atau asetnya kepada para buruh.

Walaupun dalam banyak hal konsep divestasi (divesment) selalu dipakai dalam proyek besar yang bergerak dalam sektor pertambangan yang melibatkan penanam modal asing untuk dapat mengelolanya yang bekerjasama dengan pemerintah yang dulu dengan menggunakan dasar perjanjian kontrak karya atau setelah keluarnya Undang-Undang Minerba yang baru menggunakan Izin Usaha Pertambangan (IUP) dengan ketentuan bahwa penanam modal asisng tersebut harus mau menyerahkan sebagian atau seluruhnya saham kepada pemerintah yang dituangkan dalam klausul perjanjian yang dibuat oleh penanam modal asing dengan pemerintah. Walaupun demikian, konsep divestasi saham (divesment) tersebut pada intinya adalah melakukan pelimpahan atau pelepasan saham dari suatu pemegang saham kepada pihak lain. Hal ini sebagaimana menurut Antoni K. Muda dalam kamus lengkap ekonomi menyatakan bahwa divestasi (divesment) adalah penyertaan atau pelepasan sebuah investasi seperti pelepasan saham lama. ${ }^{22}$

\section{B. Membuat Saham Baru Sebagai Modal Tambahan}

Bahwa pada dasarnya yang membedakan antara badan usaha perseroan terbatas dengan badan usaha lain seperti CV, Firma dan lainnya adalah dimana modal perusahaan

${ }^{21}$ Abdul Moin, Merger, Akuisisi, \& Divestasi, Edisi Ke-2 (Yogyakarta: Ekonisa Kampus Fakultas Ekonomi UII, 2007), 334-336.

22 Antoni K. Muda, Kamus Lengkap Ekonomi (Jakarta: Gita Media Press, 2003), hlm. 117. 
terbagi dalam bentuk saham-saham, ${ }^{23}$ dan tidak hanya itu, bahwa kemudian modal perseroan terbatas tersebut telah ditentukan minimal besarannya. ${ }^{24}$ Kemudian apabila perusahaan tersebut dalam perjalanannya membutuhkan penambahan modal, maka perusahaan dapat melakukan penambahan atas modal perusahaan dengan persetujuan RUPS dengan memperhatikan persyaratan kuorum dan jumlah suara yang setuju untuk melakukan penambahan modal dan melakukan perubahan anggaran dasar. ${ }^{25}$

Oleh karena itu maka penambahan modal oleh perusahaan ini dapat dimanfaatkan sebagai sebuah cara untu dapat mengikutsertakan pekerja/ buruh dalam hal kepmilikan saham oleh suatu perusahaan. Hal inisebagaimana diamanatkan dalam pasal 43 ayat (1) dan (3) Undang-Undang Nomor 40 Tahun 2007 tentang Perseroan Terbatas dinyatakan bahwa: ayat (1) menyatakan bahwa "seluruh saham yang dikeluarkan untuk penambahan modal harus terlebih dahulu ditawarkan kepada setiap pemegang saham seimbang dengan pemilikan saham untuk klasifikasi saham yang sama". Kemudian ayat (3) menyatakan bahwa "Penawaran sebagaimana dimaksud dalam ayat (1) tidak berlaku dalam hal pengeluaran saham: ditujukan kepada karyawan perseroan, ditujukan kepada pemegang obligasi atau efek lain yang dapat dikonversikan menjadi saham yang telah dikeluarkan dengan persetujuan RUPS, dan dilakukan dalam rangka reorganisasi dan/atau restrukturisasi yang telah disetujui oleh RUPS".

Dari ketentuan di atas pada prinsipnya pekerja/buruh memiliki hak untuk turut serta dalam hal kepemilikan saham yang ada dalam perusahaan, terhadap hal ini apabila mengacu pada pasal 41 ayat (1) dan (2) Undang-Undang Nomor 40 Tahun 2007 tentang Perseroan Terbatas ${ }^{26}$, maka hal tersebut dapat dilakukan melalui perundingan antara buruh dengan pihak perusahaan dalam Rapat Umum Pemegang Saham (RUPS), karena dalam ketentuan pasal tersebut secara hukum dapat dikatakan bahwa kepemilikan saham oleh buruh dapat dikategorikan sebagai kegiatan penambahan modal perusahaan. Oleh karena itu maka dengan adanya kepemilikan saham oleh buruh tentu saja kemudian perusahaan akan dapat mengembangakan usaha produksinya.

\section{PENUTUP}

23 Lihat Pasal 1 angka 1 Undang-Undang Nomor 40 Tahun 2007 tentang Perseroan Terbats, yang menyatakan bahwa "Perseroan Terbatas, yang selanjutnya disebut perseroan, adalah badan hukum yang merupakan persekutuan modal, didirikan berdasarkan perjanjian, melakukan kegiatan usaha dengan modal dasar yang seluruhnya terbagi dalam saham dan memenuhi persyaratan yang ditetapkan dalam undang-undang ini serta peraturan pelaksanaannya".

24 Lihat Pasal 32 ayat (1) Undang-Undang Nomor 40 Tahun 2007 tentang Perseroan Terbatas, yang menyatakan bahwa "Modal dasar Perseroan paling sedikit Rp50.000.000,00 (lima puluh juta rupiah)".

25 Lihat pasal 41 ayat (1) dan pasal 42 ayat (2) Undang-Undang Nomor 40 Tahun 2007 tentang Perseroan Terbatas.

26 Pasal 41 ayat (1) dan (2) Undang-Undang Nomor 40 Tahun 2007 tentang Perseroan Terbatas menyatakan bahwa: ayat (1) "penambahan modal perseroan dilakukan berdasarkan persetujuan RUPS". Kemudian ayat (2) "RUPS dapat menyerahkan kewenangan kepada Dewan Komisaris guna menyetujui pelaksanaan keputusan RUPS sebagaimana dimaksud pada ayat (l) untuk jangka waktu paling lama l (satu) tahun". 
Kepemilikan saham oleh buruh dalam suatu perusahaan merupakan bagian dari upaya mewujudkan sistem ekonomi Pancasila sebagaimana yang diamanatkan oleh Pancasila dan UUD 1945 dengan menjunjung tinggi asas demokrasi dan kekeluargaan di dalam kegiatan usahanya. Selain itu, bahwa kepemilikan saham oleh buruh dalam suatu perusahaan adalah upaya pemenuhan hak-hak buruh, karena dengan memiliki saham dalam perusahaan buruh dapat turut andil di dalam menentukan kebijakan perusahaan dan mampu untuk mengakses segala macam informasi suatu perusahaan secara rinci. Hal tersebut karena secara otomatis buruh menjadi bagian dari subjek yang memiliki hak untuk dapat menerima atau menolak segala laporan yang tidak sesuai dengan keadaan perusahaan. Kemudian kepemilikan saham oleh buruh dalam suatu perusahaan juga akan berdampak pada hal yang positif bagi kinerja perusahaan kedepannya, hal itu karena semua pihak kemudian merasa memiliki perusahaan sehingga kemudian mau tidak mau semua pihak secara moral dituntut untuk bagaimana dapat mengembangkan perusahaan yang ia miliki untuk kedepannya, sehingga kemudian akan mampu mewujudkan tanggungjawab bersama dalam aktivitas perekonomian.

\section{DAFTAR PUSTAKA}

Abdul Moin, Merger, Akuisisi, e Divestasi, Edisi Ke-2 (Yogyakarta: Ekonisa Kampus Fakultas Ekonomi UII, 2007).

Antoni K. Muda, Kamus Lengkap Ekonomi (Jakarta: Gita Media Press, 2003).

Badan Pusat Statistik https://www.bps.go.id/linkTabelStatis/view/id/971 diakses pada tanggal 25 Januari 2017.

G. Kartasapoetra. Dkk, Hukum Perburuhan di Indonesia Berlandaskan Pancasila (Jakarta: Sinar Grafika, 1986).

Kurniawan, Hukum Perusahaan Karakteristik Badan Usaha Berbadan Hukum dan Tidak Berbadan Hukum di Indonesia (Yogyakarta: Genta Publishing, 2014).

Lalu Husni, Pengantar Hukum Ketenagakerjaan Indonesia, Edisi Revisi Cet. Ke-10 (Jakarta: Raja Grafindo, 2010).

Mubyarto, Ekonomi Pancasila (Yogyakarta: BPFE-UGM, 2002).

Mubyarto, Demokrasi Ekonomi dan Demokrasi Industrial, dalam http://jer.mubyarto.org/edisi_17/artikel_3.htm diakses pada 25 Januari 2017

Philippe Nonet dan Selznich, Hukum Responsif, Pilihan di Masa Transisi, diterjemahkan oleh Perkumpulan untuk Pembaharuan Hukum Berbasis Masyarakat dan Ekologis (HuMa) (Jakarta: HuMa, 2003).

Revrisond Baswir, Asas Kekeluargaan, dalam http://mubyarto.org/opinilpost. php?id=5 diakses pada 25 Januari 2017

Salim HS, Hukum divestasi di Indonesia (Jakarta: Penerbit Erlangga, 2010). 
124 | Kewenangan Pemerintah Daerah dan Partisipasi Masyarakat dalam Pengelolaan Potensi Daerah

Salim HS dan Erlies Septiana Nurbani, Hukum Divestasi Di Indonesia (Pasca Putusan Mahkamah Konstitusi RI Nomor 2/SKLN-X/2012), Edisi Revisi (Jakarta: Rajawali Pers, 2013).

Satjipto Rahardjo, Ilmu Hukum, Cet. ke-8 (Bandung: PT. Citra Aditya Bakti, 2014). 